\title{
Obedience Pressure, Professional Ethics, Attitude of Skepticism and Independence Towards Audit Judgment
}

\author{
Bima Cinintya Pratama ${ }^{1}$, Zulfikar Ali Ahmad ${ }^{2}$, Maulida Nurul Innayah ${ }^{2}$ \\ 1. Fakultas Ekonomi dan Bisnis, Universitas Muhammadiyah Purwokerto \\ 2. Sekolah Tiinggi Ilmu Ekonomi Yayasan Keluarga Pahlawan Negara Yogyakarta \\ E-mail: pratamabima@gmail.com
}

\begin{abstract}
This study investigates the interaction effects of obedience pressure, professional ethics, skepticism attitude, and auditor independence towards audit judgment taken by auditors. Total samples of fifty-four Masters of Accounting and Professional Program in Accounting students were provided with a set of questionnaire to see their perceptions of audit judgments. The sample was conducted by convenience sampling method. Analyses of the data using multiple regression found that obedience pressure, professional ethics, and auditor independence significantly affect audit judgment taken by auditors. While, skepticism attitude was not significantly affect audit judgment. We argue that this was because many of our respondents were not having experience as a real auditor so that they did not have good skepticism attitude well enough that may affect their judgments.
\end{abstract}

Keywords: obedience pressure, professional ethics, skepticism attitude, auditor independence, audit judgment.

\section{Introduction}

Nowadays, the accountant profession is increasingly showing its development, this is due to the increasing public awareness of the importance of accountant services and the vast growth of private enterprises. One of the public accounting services benefit is to provide accurate and reliable information for decision making. The financial statements that have been audited by the public accountant are reasonably more reliable than the unaudited financial statements. Users of audit reports expect that the audited financial statements by public accountants are free from material misstatement, trustworthy to be used as the basis for decision-making and are in conformity with accounting principles applicable in Indonesia. Therefore, an independent and objective professional service (public accountant) is required to assess the fairness of financial statements presented by management.

On the other hand, there are many cases of companies that fall or go bankrupt due to business failures associated with auditor failure, thereby threatening the 
credibility of financial statements. Audit judgment is very important in generating audit reports. Audit judgment is required because the audit is not conducted on all evidence. This evidence is used to express an opinion on the audited financial statements, so it can be said that audit judgment also determines the results of the audit. According Mulyadi (2002) audit judgment is the auditor's policy in determining the opinion of the audit results that refers to the formation of an idea, opinion or approximation of an object, event, status, or other types of events. The threat to the credibility of these financial statements further affects the public perception, especially the users of the financial statements of the audit results. The quality of the audit results is important because high quality audit reports will produce reliable financial reports as a basis for decision making.

Auditor must be independent in issuing their opinion and in issuingtheir audit report afterwards. Arens and Loebbecke (2003) define independence in auditing means holding an impartial view in the conduct of audit testing, evaluation of audit results, and the preparation of audit reports. Without independence, being auditor does worth anything. The public does not believe in the auditor's results so that the public will not seek auditing services from the auditor. In other words, the existence of the auditor is determined by his/her independence. The second common standard (SA section 220 in SPAP, 2001) states that "In all matters relating to engagement, independence in the mental attitude must be maintained by the auditor". This standard requires that auditors be independent (not easily influenced), as they performtheir work in the public interest. Thus they are not justified to be in favor of anyone's interest, because no matter how perfect the technical expertise they possess, they will lose their independence which is very important to maintain their freedom of opinion. The independence referred above does not mean the attitudes of a prosecutor in a court case, but more like the impartiality of a judge. The auditor recognizes the obligation to be honest not only to the management and owners of the company, but also to creditors and others who place confidence in the independent auditor's report, such as prospective owners and creditors.

It is interesting to note that the public accounting profession is like a doubleedged sword. On one hand the auditor should pay attention to the credibility and professional ethics. The ethics of this profession must be more than moral principles 
(Boynton, 2003). This ethic includes the standards of conduct for a professional devoted to practical and idealistic purposes intended to direct a permanent person in the corridor of good conduct in the conduct of his profession. On the other hand, the auditor must also face pressure from the client in various decision-making. If the auditor is unable to resist the pressure of the client such as personal, emotional or financial pressure then the auditor's independence has decreased and may affect their judgment and audit quality.

In conducting their audit, the auditor performs audits with many judgment and considerations. An auditor in performing his/her duties makes audit judgment influenced by many factors, both technical and non-technical. The auditor's perspective in responding to information relates to audit responsibilities and risks to be faced by the auditor in relation to the judgment they make. Many factors influence the perception of the auditor in responding and evaluating the information and evidence they get in their audit assignments, one of which is the skepticism of the auditors themselves. The Standards of Public Accounting Professionals (SPAP), 2001: 230.2, express professional auditors' skepticism as an attitude that includes thoughts that are always questioning and critically evaluating audit evidence.

Testing on audit judgment is important because in the Public Accounting Professional Standards (SPAP), auditors are required to use professional judgment in assessing matters related to the examination. The more precise audit judgment made by the auditor the more accurate the audit results. There are still inconsistencies in the results of research on audit judgment in Indonesia (Hartanto 2001; Zulaikha 2006). This is because the judgment made by the auditor is a subjective consideration of an auditor and is highly dependent on the individual's perception of a situation.

This study aims to investigate the influence of perceptions of obedience pressure, professional ethics, skepticism, and independence on the audit judgment. The expected contributions of this research are: (1) contributing to the development of theories, especially those related to auditing and behavioral accounting, (2) providing additional empirical evidence in the accounting literature, particularly on the influence of compliance pressure, professional ethics, skepticism and independence on audit judgment, (3) provide additional description of the dynamics that occur within the auditor environment, especially in terms of audit judgment. 


\section{Method}

\section{Sample and Research Data}

The sample is part of the population that have characteristics possessed by that population. The sample represents the entire population. The sample used in this research is the Master of Accounting (MAKSI) Student of Gadjah Mada University and the Student of Accounting Profession Education (PPAK) Jenderal Soedirman University. The data used in this study is the primary data derived from the questionnaire distributed to the respondents. The respondent in this research amounted to 54 students.

\section{Operational Definition and Variable Measurement}

This study consists of 4 (four) independent variables which are obedience pressure, professional ethics, skepticism attitude, and auditor independence, and 1 (one) dependent variable which is audit judgment. The obedience pressure in this study refers to situations of conflict in which the auditor is under pressure from the employer and the audited entity to perform an action that deviates from the ethical standard. Obedience pressure was measured using the instrument adopted from the study by Jamilah, et al (2007).

Professional ethics in this study are the values of behavior accepted and used by a particular group, in this context is the auditor or accountant profession association. Professional ethical variables were measured using the instruments used by Haryono Yusuf (2002).

The attitude of skepticism in this study refers to an attitude that includes thoughts that always question and critically evaluate the audit evidence. The attitude of skepticism is measured using an instrument adopted from Hurt (2010).

Auditor independence in this study is a mental attitude that is free of influence, not controlled by others, and not dependent on others. Independence was measured using the instruments used by Elfarini (2007).

Audit judgment in this study refers to a personal judgment or an auditor's perspective in response to information affecting the documentation of evidence as well as the decision making of the auditor's opinion on the financial statements of an entity. Audit Judgment variables were measured using an instrument developed by Jamilah et al. (2007) 


\section{Analysis Method}

The data collected is tabulated first and is assigned of a value in accordance with the established rating system. The value obtained is an indicator for the independent variable pair $(\mathrm{X})$, namely the obedience pressure, professional ethics, skepticism and independence. And the dependent variable (Y) is audit judgment that is assumed in a linear relationship.

\section{Result and Discussion}

Before conducting the regression test, reliability and validity test was conducted with the data obtained from the respondents. For reliability test use parameter criterion of Cronbach Alpha> 0,7. Reliability test results show that all items are reliable. The results are: the obedience pressure $=0.798$, professional ethics $=0.873$, skepticism $=$ 0.705 , independence $=0.927$ and audit judgment perceptions $=0.766$. For the validity test in this research, Pearson parameter $<0,05$ was used. The validity test results also indicate that all items are valid as measurements.

Table 1

Reliability Test Results

\begin{tabular}{|c|l|c|c|l|}
\hline No & \multicolumn{1}{|c|}{ Variables } & $\begin{array}{c}\text { Croncbach's } \\
\text { Alpha }\end{array}$ & Number of Questions & Results \\
\hline 1 & Obedience Pressure & 0,789 & 9 & Reliable \\
\hline 2 & Professional Ethics & 0,873 & 13 & Reliable \\
\hline 3 & Skepticism & 0,705 & 10 & Reliable \\
\hline 4 & Independency & 0,927 & 7 & Reliable \\
\hline 5 & Perceptionof Audit judgment & 0,766 & 10 & Reliable \\
\hline
\end{tabular}

Source: Primary data processed

\section{Regression Analysis Results}

To predict how much strength of effect from the variables of obedience pressure, professional ethics, skepticism, and independence towards audit judgment, multiple regression analysis tools was used. The regression equation is:

$\mathrm{AJ}=\alpha+b 1 P R+b 2 E T+b 3 S K E P+b 4 I N D+e$

Where:

$\begin{array}{lll}\text { AJ } & = & \text { Audit judgment } \\ b 1-b 4 & = & \text { Regression coefficient } \\ \text { PR } & = & \text { Obedience Pressure } \\ \text { ET } & = & \text { Professional Ethics } \\ \text { SKEP } & = & \text { Skepticism } \\ \text { IND } & = & \text { Independency } \\ \mathrm{e} & = & \text { Error }\end{array}$


Then, to find the influence between independent variables with dependent variable, this study did some further testing. Statistical test F used to see the level of accuracy of a model to be able to predict the value of observations or it can be said that the model is acceptable because in accordance with the observation data. The size of the goodness of fit model (F) essentially measures the effectiveness of the model (Gudono, 2011). The $\mathrm{F}$ test results can be seen in table 2.

Table 2

The Results of $\mathrm{F}$ Test and Adjusted $R^{2}$

\begin{tabular}{|c|c|c|c|c|}
\hline F Value & F Table & Adjusted $\boldsymbol{R}^{2}$ & Sig & Conclusion \\
\hline 7,138 &. & 0,317 & 0,000 & Model Fit \\
\hline
\end{tabular}

Source: Primary data processed

$\mathrm{F}$ value calculated from the above model is 7.138 so that the value of $\mathrm{F}$ value $>\mathrm{F}$ table with probability of 0.000 , it can be said that the regression model is fit and can be used to predict audit judgment variable. Meanwhile, the $t$ test was used to determine whether each independent variable could affect the dependent variable significantly or not. The t-test serves to accept or reject the research hypothesis. Result of $t$ test can be seen in table 3.

Table 3

Results of t-test

\begin{tabular}{|l|l|l|l|l|}
\hline \multirow{2}{*}{ Variables } & \multicolumn{4}{|c|}{ Variable Dependent:Audit judgment } \\
\cline { 2 - 5 } & $\begin{array}{l}\text { Regression } \\
\text { Coefficients }\end{array}$ & t value & Sig. & Conclusion \\
\hline (Constanta) & 19,754 & 4,214 &, 000 & \\
\hline Obedience Pressure & 0,447 & 2,730 &, $009^{*}$ & H1. Supported \\
\hline Professional Ethics & $-0,302$ & $-1,939$ &, $058^{* *}$ & H2. Supported \\
\hline Skepticism & $-0,085$ &,- 692 &, 492 & H3. Not Supported \\
\hline Independency & 0,437 & 3,186 &, $003^{*}$ & H4. Supported \\
\hline$K^{2}$ Adjusted $=0,317$ & \multicolumn{5}{|l}{} \\
\hline $\begin{array}{l}* \text { Significanton 5\% } \\
\text { ** Significanton } 10 \%\end{array}$
\end{tabular}

Source: Primary data processed

Adj R Square in this model is $31.7 \%$. This means that the variables of obedience, ethics, skepticism, and independence can explain the dependent variable, audit judgment as much as $31.7 \%$, while the rest $(100 \%-31.7 \%=68.3 \%)$ is explained by other variables outside the model. 
The regression coefficient of obedience pressure variable is positive value equal to 0,447 and affect the audit judgment with value $\mathrm{p}=0,009$ at $5 \%$ significance level. This means that the higher the obedience pressure will make the audit judgment perception also higher. This is support the hypothesis 1 which states that the obedience pressure affects audit judgment significantly, then $\mathrm{H} 1$ is supported.

Professional ethics variable is significant with the level of significance $10 \%$ at $p$ $=0,058$ and obtained negative regression coefficient equal to $-0,302$ which means higher auditor professional ethics hence audit judgment perception is decreasing. This is in accordance with hypothesis 2 which states that professional ethics affects audit judgment significantly, then $\mathrm{H} 2$ is supported.

The variable of skepticism is valued $-0,085$ and did not affect the audit judgment's perception with $\mathrm{p}=-0.492$, failed to accept at $5 \%$ significance level. So the test results do not show any evidence that can be used to support $\mathrm{H} 3$.

Variable of auditor independence with 5\% significance level at $p=0,003$ obtained and has positive regression coefficient equal to 0,437 and influence to audit judgment perception which means higher auditor independence hence perception of auditor judgment is also higher. This result supports hypothesis 4 which states that the auditor's independence affects audit judgment significantly.

\section{Discussion}

Based on the results obtained, it is known that the obedience pressure shows a significance value of 0.009 which is far below 0.05 indicating that the pressure of obedience significantly affects audit judgment perception. This means that pressure from superiors will improve the perception of audit judgment conducted by the auditor. This shows the same results with the results of research from Jamilah et al (2007) and Tatiwakeng (2013) that the obedience pressure has a significant positive effect on audit judgment. From the statistical test results found evidence that supporting Hypothesis 1 (H1).

Statistical test results of professional ethical variables concluded that professional ethics has a negative effect on audit judgment perceptions. This implies that the higher the professional ethics the audit judgment perception is lower. The results of this study are in accordance with previous research from Art Fitriani, Daljono (2012) 
which explains that ethical perceptions have a significant effect on audit judgment. Hence, hypothesis 2 (H2) is accepted.

For skepticism attitude variable in this research, it is concluded that skepticism does not have an effect on audit judgment perception. This has implications that the high or low attitude of skepticism possessed by the auditor does not affect the perception of audit judgment. Researchers suspect the possibility of skepticism does not affect the perception of audit judgment because the respondent has no previous work experience in the field of audit. In accordance with Nelson's (2009) study which shows that audit knowledge gained from auditing experience will have an effect on skepticism that will affect audit judgment, but in this study, some respondents have not had previous audit work experience so when skepticism is associated with perception audit judgment it failed to support the hypothesis 3 (H3).

Variable Independence testing concluded that independence has a positive influence on audit judgment perception. This implies that the higher the independence, the perception of audit judgment obtained is also higher. This result is in accordance with the research Singgih, et al (2010) which explains that independence affects both simultaneously and partially to audit quality. Independence can help the auditor to consider audit judgment, so the audit quality will be better.

\section{Conclusion}

This study aims to determine the influence of obedience pressure, professional ethics, skepticism, and independence pressure on the perceptions of audit judgment. Based on the results of data analysis and discussion that has been explained above, there are some things that can be concluded from this research, namely: The obedience pressure has a significant influence on audit judgment perception. This shows that auditors who are under pressure of obedience will tend to keep trying to produce a good judgment audit in order to have good audit results. Professional ethics has a significant influence on the perception of audit judgment. The attitude of skepticism has no effect on the perception of audit judgment. Independence has a significant influence on the perception of audit judgment. This shows that auditors who have strong independence will be able to take a relatively better and qualified audit judgment. 


\section{References}

Arens, Alvin. A., and James K. Loebbecke. 2003. Auditing Pendekatan Terpadu. Jakarta: Salemba Empat.

Boynton, William C., and Jhonson Raymond, Walter G. Kell. 2003. Modern Auditing Edisi Ketujuh. Jakarta: Erlangga.

Elfarini, Eunike Christina. 2007. Pengaruh Kompetensi dan Independensi Auditor Terhadap Kualitas Audit. Jurnal Dinamika Akuntansi.

Fitriani, Seni and Daljono. 2012. Pengaruh Tekanan Ketaatan, Kompleksitas Tugas, Pengetahuan dan Persepsi Etis Terhadap Audit Judgement. Diponegoro Journal of Accounting, Vol.1, No.1, pp. 1-12.

Hartanto, Hansiadi Yuli and Indra Wijaya Kusuma. 2001. Analisis Pengaruh Tekanan Ketaatan Terhadap Judgment Auditor. Jurnal Akuntansi dan Manajemen. Ed. Desember, hal 1-14.

Hurt, R. Kathy. 2011. Development of a Scale to MeasureProfessional Skepticism. Auditing: A Journal of Practice \& Theory.Vol. 29, No. 1. pp. 149-171

Ikatan Akuntan Indonesia. 2001. Standar Profesional Akuntan Publik Per 1 Januari 2001. Jakarta: Salemba Empat.

Jamilah, Siti, Zaenal Fanani, and Grahita Chandrarin. 2007. Pengaruh Gender, Tekanan Ketaatan, dan Kompleksitas Tugas Terhadap Audit Judgment. Simposium Nasional Akuntansi 10, Makassar.

Mulyadi. (2002). Auditing 1 : Edisi Enam. Jakarta: Salemba Empat.

Nelson, Mark W. 2009. A Model and Literature Review of Professional Skepticism in Auditing. Auditing: A Journal of Practice \& Theory, Vol.28, No.2, pp. 1-34.

Praditaningrum, Anugrah Suci dan Indira Januarti. 2012. Analisis Faktor-Faktor yang Berpengaruh terhadap Audit Judgment (Studi pada BPK RI Perwakilan Provinsi Jawa Tengah). Simposium Nasional Akuntansi 15, Banjarmasin.

Robin, S. P., and Judge,T.A.2007. Organizational Behavior, Pearson Educations,12th ed.

Shaub, Michael K., and J. Lawrence. 1996. Ethics, Experience and Profesional Skepticism : A Situasional Analysis. Behavioral Research in Accounting. Vol.8, pp. 124-157.

Singgih, Elisha Muliani dan Icuk Rangga Bawono. 2010. Pengaruh Independensi, Pengalaman, Due Professional Care dan Akuntabilitas Terhadap Kualitas Audit. Simposium Nasional Akuntansi 13, Purwokerto

Tatiwakeng, Cindy W. 2013. Pengaruh Efikasi Diri (Self Efficacy) Kompleksitas Tugas dan Tekanaan Ketaatan terhadap Kualitas Audit judgment Auditor Internal Pemerintah. Thesis. Universitas Gadjah Mada

Yustrianthe, Rahmawati Hanny. 2012. Beberapa Faktor Yang Mempengaruhi Audit Judgment Auditor Pemerintah. Jurnal Dinamika Akuntansi, Vol.4, No.2, pp. 72-82.

Zulaikha, 2007. Pengaruh Interaksi Gender, Kompleksitas Tugas, dan Pengalaman Auditor terhadap Audit Judgment. Simposium Nasional Akuntansi 9, Padang. 